\title{
Are students with disabilities ready for college? The influence of college readiness to college engagement
}

\author{
Alies Poetri Lintangsari ${ }^{1}$, Ive Emaliana ${ }^{2}$, Fatmawati $^{3}$, Unita Werdi Rahajeng ${ }^{4}$ \\ ${ }^{1,2}$ Language Education Department, Faculty of Cultural Studies, Universitas Brawijaya, Malang, Indonesia \\ ${ }^{3}$ Culture and Art Department, Faculty of Cultural Studies, Universitas Brawijaya, Malang, Indonesia \\ ${ }^{4}$ Psychology Department, Faculty of Social and Political Sciences, Universitas Brawijaya, Malang, Indonesia
}

\begin{tabular}{l} 
Article Info \\
\hline Article history: \\
Received Feb 5, 2021 \\
Revised Jun 22, 2021 \\
Accepted Jul 13, 2021 \\
\hline
\end{tabular}

\section{Keywords:}

College engagement

College readiness

Higher education

Inclusive education

Students with disabilities

\begin{abstract}
Inclusive education is seen as promising way to accommodate students with disabilities in accessing higher education; yet, the implementation leaves challenges for the students with disabilities and also the faculties. Regarding the secondary education curriculum that is not preparing students with disabilities to attend higher education, students with disabilities are struggling in adjusting college life. This research aimed at confirming the influence of college readiness to college engagement of students with disabilities. There were 61 college students with disabilities participated in the survey on college readiness and college engagement. Independent T-Test and simple regression analysis was applied to test the hypothesis. The result showed that the college readiness influence college engagement with large effect size $(\mathrm{r}=.769>0.50, \mathrm{~F}=85.494, \mathrm{p}(.000)<0.01)$ which indicates that the more students are college-ready, the more they are engaged. Subsection's variables of gender and education background do not statistically significant affect the college readiness and engagement of students with disabilities. As the opportunity for students with disabilities attending college is uprising, college transition program is highly suggested to prepare students with disability for college life.
\end{abstract}

This is an open access article under the CC BY-SA license.

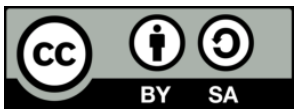

Corresponding Author:

Alies Poetri Lintangsari

Language Education Department, Faculty of Cultural Studies

Universitas Brawijaya

Jl. Veteran, Malang, East Java, Indonesia

Email: alieslintang@ub.ac.id

\section{INTRODUCTION}

Inclusive Education (IE) is a global agenda combating discrimination in education as a consequence of Salamanca Statement on Special Needs Education [1] and UN Convention on The Right of People with Disabilities (CRPD) [2]. Growing researches worldwide have reported the implementation of IE in both primary and secondary level but less attention given to the higher education, though the numbers of youth with disability participating in Higher Education is increasing in many countries [3]-[8]. In Indonesia, the inclusions of people with disabilities become the projecting national agenda since the CRPD ratification through Indonesian Law number 19 of 2011 [9]. Nevertheless, inclusion in Indonesia higher education is still in its infancy. There are only nine out of 3.270 universities [10] in Indonesia that is officially accepting Students with Disabilities (herein after termed SwD) and provide services for them. It is a fact portraying that IE in higher education level in Indonesia is still a way of attention. The implementation of IE in Indonesia is only recorded in small number of researches, most of them are concentrating on policy and management of IE in higher education [11], [12] rather than the practices that involve research on curriculum, assessment and 
instruction design. Meanwhile, curriculum, assessment, and instruction as a part of classroom practices are fundamental to promote effective and ultimate learning. It is a critical process to determine the achievement of the learning objective [13]. SwD attending university reported facing some challenges. Research done by Fuller, et al. [14] involved 173 students with disabilities reported that $44 \%$ of students face barriers that impact the learning process. They experience difficulties more than students without disabilities arouse from lecturers who tend to speak too quickly, difficulties in taking notes while listening to the lecture and difficulties in group discussion participation. There were $22 \%$ students reported barriers related to on-campus classes such as being involved to discussion session since they are not able to follow the pace of discussion and restricted question and answer session since it is found difficult to hear and see the lecturers and other peers. There were $13 \%$ of students reported barriers to off- campus learning and $21 \%$ of students reported challenges to using learning center [14]. Other researches also replicate the aforementioned research that SWD lacks of assessment choice and reasonable adjustment [15]. Drawing on previous researches, SWD is mostly facing difficulties in the learning process since the lecturers do not accommodate their needs which are different from students without disabilities. It also can be seen that SWD participation in inclusive education needs to be improved not only to facilitate the students but also to improve the lecturers competency in facilitating and engaging SwD in their classes to support their college success [8]. Despite the various research has combated the barriers of SwD by addressing the teaching and learning process, less researches have been addressing these matters from the perspectives of SwD position, yet, the SwD college preparedness is significant to predict their success in college.

Success in college is strongly related to precollege preparation [16]. Due to some considerable factors that differ the college and high school settings, Conley [17] argued that the college readiness of the students cannot be simply measured by the high school success. Therefore, academic preparedness and achievement in high school is not enough to guarantee college success. Conley [17] proposed the construct of college readiness that has many facets such as academic contents knowledge, writing skills, academic behaviors, cognitive strategies such as critical thinking and contextual skills including knowledge of college policies, expectation and coping skills. Some researchers also proposed additional facets such as motivation, college expectation, social support and self-efficacy [18]-[21]. The college-ready students are expected to be able to understand the college experience to a full understanding of the postsecondary culture and structure covering both academic and social environment. It is their first setting where they are expected to function as adults [17]. In the context of students with disabilities, various researches have reported, Chandler, et al. [22] reported that there is a growing disparity in the college readiness rates of students enrolled in special education with other counterparts, they experienced a drastically lower college readiness compared to students with economy disadvantages, students with limited English proficient, the disparity is chiefly caused by poverty.

Addressing the aforementioned gaps, college transition of students with disabilities has been projecting agenda in the special education field [23]. Various skills and knowledge have been identified to support the college success of students with disabilities such as cognitive, academic, vocational, independent living and social, students' characteristics, environmental characteristics and also interaction [24]. Morningstar, et al. [25] have proposed the frameworks of SwD's college and career readiness that associated with both academic and non-academic skills such as academic engagement, mind-sets, learning processes, critical thinking, interpersonal engagement, and transition competencies. The aforementioned prominent researches have reported the needs of college readiness skills and transition competencies that significantly contribute to the educational engagement of SwD in college. College engagement is considered as one of predictor factor to college success, in its infancy definition, some experts have elucidated the definition of college engagement as the students' investment in learning activities both cognitively and affectively highlighting that the investment is not only of time, but also attention and intellectual vitality both physically and psychologically [26], [27]. Integrated definition incorporating the college engagement has been provided by previous studies [16], [28], [29] that consists of the cognitive, affective, and behavioral aspects of college engagement encompassing the reciprocal obligation of both the students and the institution in nurturing the college engagement, it stresses the role of institution to take the responsibility in promoting its students engagement.

Internationally speaking, researches on students with disabilities in higher education have been variously postulated. Among others are barriers related to participation and inclusion in higher education compromising the limited accessible assessment options, lecturers and staffs attitudes, institutional barriers, and disclosure issues [15], [30]. In Indonesia context, similar barriers are also addressed [8], [11], [31], [32] which is specifically stressing the barriers in lecturer competencies, institutional supports, and gaps between practices and perspectives of the personals toward inclusion; yet, elaboration on the students factor toward the barriers are hardly discussed. According to Rizky [33] that identified the post-secondary education plans of SwD who enrolled in special education, $67.85 \% \mathrm{SwD}$ were planning to be employed while only $17.85 \%$ 
were interested in attending college, 3.57\% SwD were willing to be both employed and attending college, $3.57 \%$ planned to be unemployed and $7.14 \%$ did not have any plan yet. She also emphasizes the perspective of SwD toward their own self-esteem and desire to be in college. Only 25\% students who were interested and convinced that they have a chance to attend higher education, $42.85 \%$ of students thought that they have a chance to attend college but they did not have interest. The rest of the students thought they did not deserve to attend college due to their disability $(3.57 \%)$ and the economy condition $(28.57 \%)$. A study conducted by Michael [34] reported that the implementation of disability inclusion in higher education in one of state university in Indonesia has met the four criteria to fulfil the education right for SwD namely: availability (access to attend college, institutional budget, staffs and lecturers competency and also infrastructures); accessibility (affirmative program to make the university accessible); acceptability (the cultural concept of acceptance toward disability inclusion); and adaptability (the efforts made by the university to be adaptable and flexible to meet the needs of students with disabilities). Although generally the institution has met the criteria of disability inclusion, some challenges and barriers remain real for the $\mathrm{SwD}$, among others are coming from the students itself such as low self-esteem, disclosure issues, academic competencies and also social skills.

Universitas Brawijaya has formed its credential as the pioneer of disability inclusion in higher education in Indonesia since 2012. It has drawn attention of SwD in Indonesia, not only the provisions that the university made, but also the affirmative admission program that specifically designed for applicant with disabilities equipped with some enrollment test procedures which are adjusted and modified to facilitate the needs of applicants with disabilities. This affirmative programs has made as form of equity to support the equality of education for $\mathrm{SwD}$ which is historically discriminated for ages [8]. Consequently, standard adjustment should be made to make a place for the SwD, which commonly are not prepared for college in their post-secondary education. It leaves challenges not only for the students but also for the lecturer to reciprocally engaging and being engaged in teaching-learning process. Given the fact that the engagement of students is significantly support their college retention and college success [16], [24], [35], [36], this research aims at confirming the college readiness as the predictor toward college engagement of students with disabilities. Critical reviews about Indonesia government policy on postsecondary education for students with disabilities, postsecondary education practices and disability inclusion in higher education context are synthesized under the framework of college readiness and college engagement to argue the needs of transition programs for students with disabilities before attending college.

\section{RESEARCH METHOD}

\subsection{Research design}

Linear Regression statistical method was applied to see the influence of college readiness of SwD to their college engagement. Survey studies adapted the College Readiness questionnaire of Landmark College [37] and College Students Experiences Questionnaire (CSEQ) [28] were administered online with some accommodations.

\subsection{Research participants}

As shown in Table 1 , there are 61 students with disabilities participated in this survey. Table 1 shows that $75 \%$ of the participants are male amounted to 46 students with disabilities and $25 \%$ participants are female amounted to 16 students with disabilities. Hence, $50 \%$ of the participants (31 students) are deaf, $20.3 \%$ are having physical disabilities, $20.3 \%$ are having visual disabilities and $9.3 \%$ are students with autism.

Table 1. Participant's demography

\begin{tabular}{llcc}
\hline \multirow{2}{*}{ Gender } & & $\mathrm{N}$ & $\%$ \\
& Male & 46 & 73.8 \\
Education background & Female & 16 & 26.2 \\
& General school & 42 & 68.9 \\
& Segregated school & 19 & 31.1 \\
& Physical disability & 12 & 19.7 \\
& Visual disability & 13 & 21.3 \\
& Autism & 6 & 9.8 \\
\multicolumn{1}{c}{ Total } & Deaf & 31 & 49.2 \\
& & 61 & 100 \\
\hline
\end{tabular}




\subsection{Research instruments}

Two instruments were used in this research. The first is the college readiness questionnaire adapted from Landmark College Guide in assessing college readiness [37]. It consists of five dimensions to measures students' college readiness, namely: the academic skills; self-understanding (metacognition); self-advocacy; executive function; and motivation and confidence. The instrument is free to use with credential citation.

The second instrument is College Students Experiences Questionnaire developed by Pace since 1979 from Indiana University and has been widely used by renowned universities all over the worlds to measure students engagement in college activities [29]. CSEQ consists of 4 parts; part 1 is College Activities measuring the quality of efforts performed by the students to interact with their campus environment; part 2 is College Environment measuring the student's perceptions of the psychological climate for learning; the third part is Estimate of Gains asking students to reflect on their entire experience at the institution and to estimate how much progress they feel in their college time; and part 4 is the additional questions that provide space for the researcher to elaborate additional data [29]. The license use of the CSEQ for this research has been granted by the Center for Postsecondary Research, Indiana University by the date of 8 December 2019.

The validity and reliability measurement are conducted to validate the item of questions. It employed the correlational statistic considering the coefficient score of Alpha Cronbach. Based on the statistical calculation, both of the questionnaires are valid and reliable with the coefficient of Alpha Cronbach is bigger than 0.6 (College Readiness Questionnaire Alpha Cronbach=0.746, CSEQ Alpha Cronbach=0.749).

\subsection{Research procedures}

Simple regression analysis was applied utilized JASP software. It is used to predict the value of the dependent variable Y (College Engagement) by the values of the independent variable X (College readiness) [38]. Data was interpreted by firstly ensuring the significant values of the statistical testing by finding the $\mathrm{p}$ value (statistically significant is the $\mathrm{p}$ values $<0.05$ [38], [39]). Descriptive statistic and independent $t$-test procedure was also previously conducted to describe the data and to compare the differences in college readiness and college engagement by education background and gender variance.

\section{RESULTS AND DISCUSSION}

\subsection{Findings}

Descriptive statistic and independent t-test was previously applied as preliminary testing to examine whether the subsections (gender and education background) affect the college readiness and engagement of students with disabilities. Of 61 respondents, 19 of them graduated from segregated school (or commonly known as special school) and 42 students graduated from general school. The participants consist of 16 female and 45 male students that experience various disabilities such as deaf, visual disabilities, physical disability, and autism as previously presented in Table 1.

Table 2 presents the variance in college readiness and college engagement between the subsections of the sample that reported based on the academic background and gender. The findings reported that the education background does not statistically insignificant to the score of college readiness $(t=.-476, p=.636)$ and college engagement $(\mathrm{t}=.439, \mathrm{p}=.662)$. It indicates that the students who graduated from general school and students who graduated from segregated school do not perform statistically different scores on both college readiness and engagement. However, students graduated from general school performed slightly lower score of college engagement $(\mathrm{M}=104.2619, \mathrm{SD}=21.32908)$ than students graduated from general school $(\mathrm{M}=106.8947, \mathrm{SD}=22.51887)$ although they have a better college readiness $(\mathrm{M}=74.9286$, $\mathrm{SD}=9.99364)$ than those who graduated from segregated school (M=73.5789, SD-10.79771).

Table 2. Preliminary testing result

\begin{tabular}{|c|c|c|c|c|c|c|}
\hline \multicolumn{2}{|c|}{ Variables } & $\mathrm{N}$ & Mean & SD & $\mathrm{t}$ & $\mathrm{p}$ \\
\hline \multirow[t]{6}{*}{ Education background } & College engagement & & & & \multirow[t]{3}{*}{-0.476} & \multirow[t]{3}{*}{0.636} \\
\hline & Segregated school & 19 & 106.8947 & 22.51887 & & \\
\hline & General school & 42 & 104.2619 & 21.32908 & & \\
\hline & College readiness & & & & \multirow[t]{3}{*}{0.439} & \multirow[t]{3}{*}{0.662} \\
\hline & Segregated school & 19 & 73.5789 & 10.79771 & & \\
\hline & General school & 42 & 74.9286 & 9.99364 & & \\
\hline \multirow[t]{6}{*}{ Gender } & College engagement & & & & 1.856 & 0.258 \\
\hline & Female & 16 & 113.5000 & 28.43472 & \multirow{5}{*}{1.143} & \multirow{5}{*}{0.258} \\
\hline & Male & 45 & 102.0889 & 17.96818 & & \\
\hline & College readiness & & & & & \\
\hline & Female & 16 & 77.0000 & 13.10471 & & \\
\hline & Male & 45 & 73.6222 & 8.92720 & & \\
\hline
\end{tabular}


The similar result also applied to gender subsection that do not significantly affect the college readiness $(\mathrm{t}=1.856, \mathrm{p}=0.258)$ and college engagement $(\mathrm{t}=1.143, \mathrm{p}=0.258)$. The findings reveal that female student $(\mathrm{M}=113.5000, \mathrm{SD}=10.79771)$ were insignificantly having better college engagement. However, female students reported to have a higher college readiness score $(\mathrm{M}=77.000, \mathrm{SD}=13.10471)$ and college engagement score $(M=113.5000, S D=28.43472)$ rather than male students' college readiness $(M=73.6222$, $\mathrm{SD}=8.92720)$ and male students' college engagement $(\mathrm{M}=102.0889, \mathrm{SD}=17.96818)$.

As aforementioned exploratory, there is no significant difference between the variables (college readiness and college engagement) and the subsections (gender and education background). It indicates that gender and education background do not affect the college readiness and college engagement of SwD. Hypothesis testing as displayed in Table 3 was examined by the application of simple regression analysis. The result shows that the college readiness significantly influence the college engagement of student with disabilities with the large effect size $(\mathrm{r}=.769>0.50, \mathrm{~F}=85.494, \mathrm{p}(.000)<0.01)$. It indicates that the more ready the students to college will positively affect their engagement. However, the college readiness accounted for $59 \%$ of variance within college engagement of students with disabilities as presented by the $\mathrm{R}$ square $\left(\mathrm{R}^{2}=.592\right)$.

Table 3. Simple regression analysis result

\begin{tabular}{cccc}
\hline Variables & $\mathrm{F}(p)$ & $\mathrm{r}(p)$ & $\mathrm{R}^{2}$ \\
\hline Readiness * Engagement & $85.494(<0.001)$ & $0.769(<0.001)$ & 0.592 \\
\hline
\end{tabular}

\subsection{Discussion}

This current study sought to approve the premise of the relation between college readiness and college engagement of students with disabilities. Participants are the college students of Universitas Brawijaya amounted to 61 participants with various types of disabilities including blinds, deaf, physical disabilities, students with autism and students with learning disabilities. They graduated from senior high school (42 students) and special senior high school (19 students). They have enrolled the Universitas Brawijaya through an affirmative admission program called as Institutional based admission for Students with Disability (SMPD). The admission program is an affirmative program that facilitate the needs of students with disabilities with an adjusted and modified test procedures that meet the capacity of SwD. This affirmative enrollment test is part of equity to support equality education for SwD as the national college entrance exam is not accessible for them. Simple regression analysis was applied with college readiness as the independent variable and college engagement as the dependent variable. The statistical result demonstrates a significant impact of college readiness toward college engagement, with large effect size $(\mathrm{r}=.769>0.50, \mathrm{~F}=85.494, \mathrm{p}(.000)<0.01)$ indicates that the college readiness variable significantly influences the college engagement of students with disability, in other word, the more ready the students, the more engaged they are in college. This research result support the previous research that assume that College Readiness of SwD plays significant roles to support their college engagement [23], [40].

Gender and education background of the participants is not affecting the college readiness and engagement as statistically proven by the independent $t$ test (Table 2). However, there is a slightly different result between students from general school that performed better college readiness $(\mathrm{M}=74.9286$, $\mathrm{SD}=9.99364)$ but having lower college engagement $(\mathrm{M}=104.2619, \mathrm{SD}=21.32908)$ compared to students graduated from segregated school that performed lower college readiness (M=73.5789, SD-10.79771), but having better college engagement $(\mathrm{M}=106.8947, \mathrm{SD}=22.51887)$. For gender subsection, slightly different performance also found between female and male students both in college readiness and engagement, female students show higher college readiness $(\mathrm{M}=77.000, \mathrm{SD}=13.10471)$ and college engagement score $(\mathrm{M}=113.5000, \mathrm{SD}=28.43472)$ rather than male students that performed lower college readiness $(\mathrm{M}=73.6222$; $\mathrm{SD}=8.92720)$ and college engagement $(\mathrm{M}=102.0889, \mathrm{SD}=17.96818)$. The findings of this research highlighted that the college readiness and college engagement of students with disabilities are not affected by the gender or education background. It indicates that both of female and male students are at the similar stage of college readiness and college engagement. The education background also did not affect the college readiness and college engagement of the students with disabilities; whether those graduated from general or segregated schools are equally having the same stage of college readiness and college engagement. It seems that the type of education background (their previous education level or their secondary education) does not significantly contribute to the college preparedness of students with disabilities.

Related to the primary and secondary education for children with disabilities in Indonesia, Dewi and Soebijarto [41] reported the determinants of school participation of children with disabilities in Indonesia. They further elaborated that the significant determinant affecting the school of participation is the degree of disabilities. Children with disabilities who are able to do self-care is 4.677 have a bigger school participation 
rather than those whose multiple disabilities [41]. Other determinants are also reported such as economy condition, living distance (those who live in cities are having better school participation rate than those who live in rural area), the availability of schools, and the degree of disability [41]. Examining the data of segregated school (or commonly known as Special Needs School) in Indonesia, there is discrepancy of the amount of school in each level, as reported by Data Center and Statistics of Ministry of Education and Culture that the higher the school level the fewer the amount is (special primary school=169; special junior secondary school=93; and special senior secondary school=69) [42]. The fewer number of schools in the higher degree indicates that the opportunity of SwD to study at higher level is less than in primary level. The data also shows that from the total 25.691 classroom, only 5.912 classroom are having a good condition, 16.665 are having minor damage, 2.191 are having moderate damage and 923 are having major damage [42]. The data indicates that most of special schools a school where most of children with disabilities study are not well infrastructural supported.

Aforementioned exploration on the infrastructures and availability of special schools in various level demonstrate that the government less concern on the sustainability and the improvement of quality education of students with disabilities. Despite the feeble support in infrastructures, Indonesia government has postulated law to support the education quality of SwD such as law number 20 of 2003 about national education, law number 8 of 2018 about people with disabilities, law of National Education Ministry number 70 of 2009 about inclusive education for SwD or gifted students, and ministry law of research, technology and higher education number 46 of 2017 about special education in higher education. All the laws have suggested the quality education for SwD under the frameworks of inclusive education and special education. In relation to student's preparation to college, none of the laws have explicitly suggested specific programs that facilitate and support schools preparing the SwD to college.

College life provides a totally different setting for $\mathrm{SwD}$, it is the initial stage where they learn to be an adult that requires some specific skills to survive not only academically but also physically and psychologically [16]. Students engagement are closely related with students retention that support students outcomes and lead to college success [43], [44]. Various research has been exploring the engagement of SwD in college, Hendrickson, et al. [45] reported that there is no significant differences between the engagement of students with intellectual disability with first year students, with appropriate supports, students with intellectual disabilities may perform comprehensive participation and benefit college as much as first year students. Bimantoro, et al. [46] reported the engagement of Blind student in English class that is improved by the implementation of differentiated by the teacher. It is for what Powers, et al. [47] has argued that provide the professional development experiences to the teacher to develop personalized learning environments is significant in improving students engagement. Lintangsari, et al. [48] research finding also support that the role of teacher is crucial to improve students engagement, she argued that blindness is not the impediment in college engagement but teacher attitude and teaching approach, as long as teacher attitude is positive and the teaching approach is accommodative, blind students will have engagement as good as sighted students. Brand, et al. [49] and Ekelman, et al. [50] argued that the occupational experience such as internship, work experiences, cooperative education, and service learning can increase greater engagement of SwD.

Road to college success for SwD are both influenced by their college readiness and college engagement. Some researchers have explored the transition program to support SwD attending college life. Researches described the transition program done in inclusive junior secondary school that involved students with autism and students with intellectual disabilities, it explains the process of transition programs that benefit the extracurricular program of self-developing in the form of handicraft, cooperation with companies and marketing skills [51], [52]. Intriguingly, a study done Mumpuniarti, et al. [53] revealed the teacher perspective toward transition program, they believe that vocational training transition program is the only effective program to support students with intellectual disabilities. The main challenge of transition program is the limited professional teachers and unstandardized professional recognition for transition professional teachers [54].

\section{CONCLUSION}

This current study confirmed the influence of college readiness to college engagement of students with disabilities. As the data reveals that the gender and education background do not interfere the college readiness and engagement of students with disabilities, it indicates that the general situation of students with disability comes in similar pattern. Revisiting the facts that the implementation of quality education for students with disability leaves room to grow, some professionals has initiated the transition program although it is not legally advised by the government, yet, those transition program has not prepared students with disability to attend college but equip them with vocational skills. It indicates that students with disabilities (especially intellectual disability) are not projected to attend college; yet, other study proved that students 
with (intellectual) disabilities perform the similar college engagement with first year college students as long as they are well supported.

The transition program is significant to prepare students with disability attending college, yet, less practices found related to college transition program as well as less government-based enforcement toward this, whereas, Indonesia college now have opened the wider door for students with disabilities to study at college. This action should be supported by the secondary education curriculum that prepares students with disabilities to attend college. College transition program is highly suggested as the emergency agenda to improve college readiness and college engagement of students with disabilities. The collaboration among schools, government and higher education institution is recommended to formulate the effective and ideal college transition program. Teacher recognition should also be considered to sustain the program. Inclusion is the projecting agenda that requires collaboration, innovation, consistency and sustainability.

\section{ACKNOWLEDGEMENTS}

The authors would deliver gratitude to Center for Postsecondary Research, Indiana Univeristy for the license use of CSEQ and also for Landmark University for the free use College Readiness Questionnaires. The authors would also thank to the editors for the insightful feedback. This paper is part of the research grant funded by LPPM Universitas Brawijaya. The authors also appreciate all the students with disabilities who took part in this survey.

\section{REFERENCES}

[1] World Conference on Special Needs Education: Access and Quality. The Salamanca Statement and Framework for Action on Special Needs Education. UNESCO, 1994.

[2] United Nation, Convention on the Rights of Persons with Disabilities (A/RES/61/106), 2007.

[3] B. Poernomo, "The Implementation of Inclusive Education in Indonesia: Current Problems and Challenges," American International Journal of Social Science, vol. 5, no. 3, pp. 144-150, 2016.

[4] A. Moriña and B. Morgado, "University surroundings and infrastructures that are accessible and inclusive for all: listening to students with disabilities," J. Furth. High. Educ., vol. 42, no. 1, pp. 13-23, 2018, doi: 10.1080/0309877X.2016.1188900.

[5] K. M. Florence, "Understanding College Preparedness of First-Semester College Students," UNLV Theses, Dissertations, Professional Papers, and Capstones, 2017, doi: http://dx.doi.org/10.34917/10985884.

[6] J. E. Cannon and S. Kirby, "Grammar structures and deaf and hard of hearing students: A review of past performance and a report of new findings," Am. Ann. Deaf, vol. 158, no. 3, pp. 292-310, 2013, doi: 10.1353/aad.2013.0027.

[7] A. Moriña, R. López-Gavira, and V. M. Molina, "What if we could Imagine an Ideal University? Narratives by Students with Disabilities," Int. J. Disabil. Dev. Educ., vol. 64, no. 4, pp. 353-367, 2017, doi: 10.1080/1034912X.2016.1228856.

[8] A. P. Lintangsari and I. Emaliana, "Inclusive education services for the blind: Values, roles, and challenges of university EFL teachers," Int. J. Eval. Res. Educ. (IJERE), vol. 9, no. 2, pp. 439-447, Jun. 2020, doi: 10.11591/ijere.v9i2.20436.

[9] Laws of the Republic Indonesia, Number 19, Year 2011. Ratification of Convention on The Rights of Persons with Disabilities, (in Bahasa), 2011.

[10] Nuraini, S. Wahyuni, T. Windiarto, E. Oktavia, and Y. Karyono, Indonesian Citizen Profile of 2015. Jakarta: Badan Pusat Statistik, 2015.

[11] E. Despalantri, "The Implementation of Inclusive Education in Junior High School of Payakumbuh City based on Index for Inclusion,” Master Thesis, Universitas Pendidikan Indonesia, 2014.

[12] Sunardi, M. Yusuf, Gunarhadi, Priyono, and J. L. Yeager, "The implementation of inclusive education for students with special needs in Indonesia," Excell. High. Educ., vol. 2, no. 1, pp. 1-10, 2011, doi: 10.5195/ehe.2011.27.

[13] C. A. Jones, Assessment for learning. London: Learning and Skills Development Agency, 2005.

[14] M. Fuller, M. Healey, A. Bradley, and T. Hall, "Barriers to learning: A systematic study of the experience of disabled students in one university," Stud. High. Educ., vol. 29, no. 3, pp. 303-318, 2004, doi: $10.1080 / 03075070410001682592$.

[15] L. Kendall, "Higher education and disability: Exploring student experiences," Cogent Educ., vol. 3, no. 1, 2016, doi: 10.1080/2331186X.2016.1256142.

[16] G. Kuh, "What Student Engagement Data Tell Us about College Readiness," Peer Rev., vol. 9, no. 1, p. 4, 2007.

[17] D. T. Conley, Redefining college readiness. Eugene, OR: Educational Policy Improvement Center, 2007.

[18] D. Allen, "Desire to finish college: An empirical link between motivation and persistence," Res. High. Educ., vol. 40, no. 4, pp. 461-485, 1999, doi: 10.1023/A:1018740226006.

[19] A. Zajacova, S. M. Lynch, and T. J. Espenshade, "Self-efficacy, stress, and academic success in college," Res. High. Educ., vol. 46, no. 6, pp. 677-706, 2005, doi: 10.1007/s11162-004-4139-z.

[20] S. M. Pancer, B. Hunsberger, M. W. Pratt, and S. Alisat, "Cognitive complexity of expectations and adjustment to university in the first year," J. Adolesc. Res., vol. 15, no. 1, pp. 38-55, 2000, doi: 10.1177/0743558400151003. 
[21] L. M. Jackson, S. M. Pancer, M. W. Pratt, and B. E. Hunsberger, "Great expectations: The relation between expectancies and adjustment during the transition to university," J. Appl. Soc. Psychol., vol. 30, no. 10, pp. 2100-2125, 2000, doi: 10.1111/j.1559-1816.2000.tb02427.x.

[22] J. Chandler, J. Slate, G. Moore, and W. Barnes, "College-readiness rates of students with special learning needs in Texas public schools," J. Educ. Hum. Dev., vol. 3, no. 2, pp. 67-103, 2014.

[23] A. Milsom and D. Lauren, "Defining College Readiness for Students with Learning Disabilities: A Delphi Study," Prof. Sch. Couns., vol. 12, no. 4, 2009, doi: 10.1177/2156759x0901200405.

[24] S. Kilpatrick, S. Johns, R. Barnes, S. Fischer, D. McLennan, and K. Magnussen, "Exploring the retention and success of students with disability in Australian higher education," Int. J. Incl. Educ., vol. 21, no. 7, pp. 747-762, 2017, doi: 10.1080/13603116.2016.1251980.

[25] M. E. Morningstar, A. Lombardi, C. H. Fowler, and D. W. Test, "A college and career readiness framework for secondary students with disabilities," Career Dev. Transit. Except. Individ., vol. 40, no. 2, pp. 79-91, 2017, doi: $10.1177 / 2165143415589926$.

[26] A. W. Astin, "Student involvement: A developmental theory for higher education," Journal of College Student Development, vol. 40, no. 5, pp. 518-529, 1999.

[27] B. Mandernach, "Assessment of student engagement in higher education: A synthesis of literature and assessment tools," Int. J. Learn. Teach. Educ. Res., vol. 12, no. 2, pp. 1-14, 2015.

[28] R. M. Gonyea, K. Kish, G. D. Kuh, R. Muthiah, and A. Thomas, College Student Experiences Questionnaire: Norms for the Fourth Edition. Bloomington, IN: Indiana University Center for Postsecondary Research, Policy, and Planning., 2003.

[29] C. R. Pace and G. D. Kuh, College Student Experiences Questionnaire. Blommington: Indiana University Center for Postsecondary Research, Policy and Planning, 1998.

[30] T. Majoko, "Participation in higher education: Voices of students with disabilities," Cogent Educ., vol. 5, no. 1, pp. 1-17, 2018, doi: 10.1080/2331186X.2018.1542761.

[31] Regulation of the Minister of National Education of the Republic Indonesia, Number 70 Year 2009. Inclusive Education for Students with Disabilitieas and Gifted Student, (in Bahasa), 2009.

[32] Y. S. Hartono, "Index for Inclusion in Elementary School of Musi Banyuasin District: A Study on the Successful Implementation of Inclusive Education of 2010," (in Bahasa), Master Thesis, Universitas Pendidikan Indonesia, 2010. [Online]. Available: http://repository.upi.edu/9100.

[33] U. F. Rizky, "Need Analysis of Students with Disabilities After Senior High School," (in Bahasa), IJDS: Indonesian Journal of Disability Studies, vol. 1, no. 1, pp. 52-59, 2014, [Online]. Available: https://ijds.ub.ac.id/index.php/ijds/article/view/10.

[34] D. Michael, "Higher Education for Students with Disabilities in Universitas Brawijaya," (in Bahasa), Jurnal HAM, vol. 11, no. 2, pp. 201-217, 2020, doi: 10.30641/ham.2020.11.201-217.

[35] D. Armstrong and A. Cairnduff, "Inclusion in higher education: Issues in university-school partnership," Int. J. Incl. Educ., vol. 16, no. 9, pp. 917-928, 2012, doi: 10.1080/13603116.2011.636235.

[36] M. Grenier, "Moving to inclusion: A socio-cultural analysis of practice," Int. J. Incl. Educ., vol. 14, no. 4, pp. 387-400, 2010, doi: 10.1080/13603110802504598.

[37] Landmark College, "A Guide To Assessing College Readines” Landmark College, Putnet, Vermont, 2009.

[38] W. E. Wagner, Using IBM SPSS Statistics for Research Methods and Social Science Statistics, 5th ed. United States of America: Sage Publication, 2015.

[39] P. Connoly, Quantitative Data Analysis in Education: A Critical Introduction using SPSS. New York: Routledge, Taylor and Francis Group, 2007.

[40] C. Abreu-Ellis, J. Ellis, and R. Hayes, "College preparedness and time of learning disability identification," J. Dev. Educ., vol. 32, no. 3, pp. 28-38, 2009.

[41] D. C. Dewi and E. Soebijarto, "School Participation Determinants of Students with Disabilities in 2015," (in Bahasa), Jurnal Aplikasi Statistika \& Komputasi Statistik, vol. 11, no. 2, pp. 15-28, 2020, doi: 10.34123/jurnalasks.v11i2.131.

[42] Ministry of Education, Culture, Research and Technology of the Republic Indonesia, PLB (Pendidikan Luar Biasa) Statistic 2019/2020. Pusat Data dan Teknologi Informasi, Jakarta 2020. [Online]. Available: http://repositori.kemdikbud.go.id/18304.

[43] T. L. Strayhorn, "How College Students' Engagement Affects Personal and Social Learning Outcomes," J. Coll. Character, vol. 10, no. 2, 2008, doi: 10.2202/1940-1639.1071.

[44] M. Tight, "Student retention and engagement in higher education," J. Furth. High. Educ., vol. 44, no. 5, pp. 689-704, 2020, doi: 10.1080/0309877X.2019.1576860.

[45] J. M. Hendrickson, W. J. Therrien, D. D. Weeden, E. Pascarella, and J. L. Hosp, "Engagement among students with intellectual disabilities and first year students: A comparison,” J. Stud. Aff. Res. Pract., vol. 52, no. 2, pp. 204-219, 2015, doi: 10.1080/19496591.2015.1041872.

[46] B. Bimantoro, A. P. Lintangsari, and D. Wulandari, "Engaging Blind Student in English Translation Class: A Report on Differentiated Instruction Implementation," Educ. English as Foreign Lang., vol. 4, no. 1, pp. 19-36, 2021, doi: 10.21776/ub.educafl.2021.004.01.03.

[47] K. Powers, S. H. Shin, K. S. Hagans, and M. Cordova, "The Impact of a Teacher Professional Development Program on Student Engagement," Int. J. Sch. Educ. Psychol., vol. 3, no. 4, pp. 231-240, 2015, doi: 10.1080/21683603.2015.1064840 
[48] A. P. Lintangsari, I. Emaliana, and F. Fatmawati, "Blind Students Engagement in Language Learning: Challenges and Opportunities," in 3rd International Language and Tourism Conference, 2019, pp. 224-234.

[49] B. Brand, A. Valent, and L. Danielson, "Improving College and Career Readiness for Students with Disabilities," American Institutes for Research, 2013.

[50] B. Ekelman, S. Bazyk, and J. Bazyk, "The relationship between occupational engagement and well-being from the perspective of university students with disabilities," J. Occup. Sci., vol. 20, no. 3, pp. 236-252, 2013, doi: 10.1080/14427591.2012.716360.

[51] D. I. P. Sari and Budiyanto, "Implementation of Transition Program for Students with Autism in State Junior Highschool 4 Sidoarjo," (in Bahasa), Jurnal Pendidikan Khusus, vol. 8, no. 1, pp. 1-10, 2016. [Online]. Available: https://jurnalmahasiswa.unesa.ac.id/index.php/jurnal-pendidikan-khusus/article/view/15321.

[52] D. S. Nanda, "The Implementation of Post-Schooling Transition Program for Students with Intelectual Disability in Special Education Centre of Payakumbuh,” (in Bahasa), J. Penelitian Pendidik. Khusus, vol. 3, no. 3, pp. 557-563, 2014. [Online]. Available: http://ejournal.unp.ac.id/index.php/jupekhu/article/view/3878.

[53] Mumpuniarti, T. Suharmini, and N. Praptiningrumm, "The Effectivement of Post-Schooling program to support the independence of Students with Intellectual Disability," (in Bahasa), Jurnal Penelitian dan Pengembangan Pendidikan Luar Biasa, vol. 1, no. 2, pp. 97-104, 2014. [Online]. Available: http://journal2.um.ac.id/index.php/jppplb/article/view/4308.

[54] N. Azizah, "Special Education Teacher Competence in Transition Education," J. Spec. Educ., vol. 12, no. 1, pp. 1-13, 2017, doi: 10.21831/jpk.v12i1.12517. 